\title{
J184013
}

\section{ドライバーの行動計測に基づく 予防型運輸安全マネジメント支援システムの検討*}

\author{
天野 圭子 ${ }^{* 1}$, 野間 春生 ${ }^{* 1}$, 多田 昌裕 ${ }^{* 1}$

\begin{abstract}
A Trial Design of Active Safety Management System for Transportation Based on Driving
\end{abstract} \\ Behavior Monitoring \\ Keiko AMANO ${ }^{* 1}$ Haruo NOMA ${ }^{* 1}$ and Masahiro TADA ${ }^{* 1}$ \\ ${ }^{1}$ Advanced Telecommunications Research Institute International, \\ 2-2-2Hikaridai, Seika-cho, Soraku-gun, Kyoto, 619-0288, Japan \\ Since 2006, Japanese government requires all transportation companies to establish a safety management system (SMS). \\ SMS is a framework for all members from top management to frontline employees to work as one to achieve safety. \\ Therefore, giving safety training to their drivers in effective and efficient way have become important issues for \\ transportation companies. To clarify transportation companies' needs for SMS support system, we have surveyed reports of \\ transportation companies' approaches for achieving safety collected by MLIT, and interviewed to 16 vehicle operations \\ managers of transportation companies. As a result of interviews, we have found out that managers have a wish to detect \\ potentially dangerous situations as well as explicitly dangerous situations, and to quantitatively score each driver's skill to \\ give personalized safety advice. However current equipments for SMS such as event data recorders can only detect explicitly \\ dangerous situations. In this paper, based on transportation companies' needs clarified through interviews, we study SMS \\ support system which can (1) automatically detect potentially dangerous situations, and (2) automatically score each driver's \\ skill according to detected situations.
}

Key Words : Transportation Safety Management, Automatic Evaluation of Driving Skill, Real-time Driving Advice

\section{1. 粕言}

運輸業界では，規制緩和による新規参入事業者の増大に伴って企業間の競争が激化しており，特に経験の浅い ドライバーの増加による事故リスクの増大が懸念されている. 一方, 2006 年に国土交通省によって, 全運輸事業 者に事故防止・安全対策の立案·実施を義務付ける運輸安全マネジメント制度が導入 (2009 年改正) されて以降, 自社ドライバーに対し効率的かつ効果的に安全指導をすることが, 運輸事業者の重要な課題となっている.

国土交通省が策定した運輸事業者向け安全教育マニュアル (1)では, 管理者はドライバー毎の運転特性を把握し, それをドライバー本人への指導に反映させること, ドライバーはヒヤリハット・色険予知訓練等により運転時の 安全意識向上をはかること，また業務中に発生したヒヤリハットや事故などの情報は組織内で共有すること，な ぞが求められている.

従来, 運行管理のために，車両位置，速度，エンジン回転数などを記録するデジタルタコグラフや，車両の前 方映像を記録するドライブレコーダが用いられてきた．なかでも，ドライブレコーダは事故やヒヤリハット事例 の収集を目的として広く利用されている。

ドライブレコーダは，急減速や急加速など車両挙動の急激な変化があれば，それを事故やヒヤリハットなど危 険が顕在化した状況の発生とみなしている.しかしながら，危険が顕在化した状況以外にも危険な状況は存在す る. 例えば，見通しの悪い交差点に安全確認もせずに速度超過で進入する行為は極めて危険であるが，運よく周

\footnotetext{
${ }^{* 1}$ 非会員, 国際電気通信基礎技術研究所（广619-0288 京都府相楽郡精華町光台 2-2-2）

E-mail: k.amano@atr.jp
}

[No.12-1］日本機械学会 2012 年度年次大会講演論文集 [2012.9.9-12, 金沢] 
册に対向車や歩行者がいなければ，結果的に何も起こらないこのような，運よく危険が顕在化しなかった “潜 在的に危険な状況”をドライブレコーダで検出することは困難である.すなおち，現状のドライブレコーダでは ヒヤリハットが起きた後の “事後対策” は可能だが，ヒヤリハットを未然に防ぐ“予防的な措置”をとることは そもそも想定されていない，そのため，潜任的に危険な運転や状況を早期に検知し、危険が顕任化する前にヒヤ リハットや事故を未然に防ぐ予防型運輸安全マネジメント支援システムの検討が必要と考えられる.

本研究では，運輸事業者の運行管理担当者（以下、運行管理者）に対するヒアリング調査によって運輸事業者 の安全管理の現状とニーズを整理した上で，予防型運輸安全マネジメント支援システムの仕様に関する検討・試 作を行い，その有用性を評価する．なお，本研究では運輸事業者のうち，トラック事業者およびバス事業者をヒ アリング調査の対象とした.

\section{2. 運輸事業者の安全管理の現状とニース}

\section{$2 \cdot 1$ 国土交通省が公表している運輸安全取組みの先進事例の整理}

運輸事業者の安全管理の現状を把握するために，まず，国土交通省によって公表されている運輸安全取組みの 先進事例 (2)の整理を行った. 国土交通省による事例公表は, 運輸安全マネジメント制度改正後の 2010 年 4 月から 開始され，2012 年 7 月現在 16 事業者（うち，トラック 9 事業者，バス 7 事業者）の事例が掲載されている.こ のうち，ドライバーに対する安全指導に取り組んでいたのは 9 事業者（56.3\%）であった。取組の主な内容は以 下のとおりである。 まず，ドライブレコーダによるヒヤリハットや事故の映像データを教材として，ドライバー 間で事故の状況や原因，再発防止のための対策を話し合い，その結果を社内で共有するという取り組みを 6 事業 者（37.5\%）が行っていた．また，専門知識を有する専任の指導員が業務に同行して，ドライバーに安全上改善 すべき点があれば指導を行う添乗指導を 3 事業者（18.8\%）が実施していた.

しかし，公表されている事例のみでは，(1)運行管理者の管理体制や(2)運行管理システムの活用状況，そして特 に (3)現状の取り組みに対して運行管理者自身が感じている課題, など運輸事業者のニーズを顕在化するための 情報が十分には得られない，そこで，これら 3 点を明らかにするため運輸事業者に対するヒアリング調査を実施 した.

\section{$2 \cdot 2$ 運輸事莱者に対するヒアリング調查結果}

前述の $2 \cdot 1$ の結果を踏まえ, 近畿圏の運輸事業者 10 事業者（うち,トラック 8 事業者, バス 2 事業者）に所属 する運行管理者 16 名に対して，2011 年 12 月から 2012 年 4 月にかけてヒアリング調査を行った. 対象事業者の 概要は表 1 に示すとおりである.

(1) 運行管理者の管理体制

9 事業者(90.0\%)で運行管理者を複数名置いているものの，いずれも他の業務を兼務して扝り，専任の運行管理 者を置いている事業者はなかった．ドライバーに対する安全指導の取り組みとしては， 8 事業者 $(80.0 \%)$ が添乗指 導を実施していたものの，いずれも専任の指導員は設けておらず，運行管理者，あるいは経験の長いドライバー が実技指導を行っていた.

(2)既存の運行管理システムの活用状況

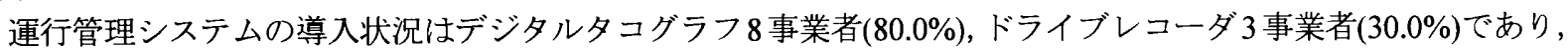
9 事業者(90.0\%)がいずれか一方を導入していた。 ドライブレコーダの活用方法は，ヒヤリハットや事故が起きた 際の情報収集・分析に加え，事故やヒヤリハットデータを教材としたドライバー間の情報共有や危険予知訓練な どであり，国土交通省の公表事例との差異は認められなかった．デジタルタコグラフの活用方法としては，速度 超過や急減速・急加速の頻度によってドライバーの技能を得点化する機能を利用し，8 事業者 $(80.0 \%)$ がドライバ 一一人一人評価と指導を行っており，うち 4 事業者 $(40.0 \%)$ 仿社内の全ドライバーの順位付けを行っていた.

(3) 安全管理体制における課題とニーズ

ヒアリング調査によって明らかとなった, 運行管理者が感じている現状の課題とニーズについて以下で述べる.

(a) 潜在的に危険なヒヤリハットの検出 : 多くの事業者が，自社のドライバーに対してヒヤリハットが発生し た際の報告を義務付けているが，ドライバーからの報告はほとんど上がってこないと述べている.しかし 
ながら，実際に添乗指導をしてみると，見通しの悪い交差点で安尒確認を䍐ったまま進入する，など運行 管理者から見るとヒヤリハットとみなせる事例が多く発生しているにもかかわらず，ドライバー自身がそ れをヒヤリハットであると認識できていないため，報告されずに放置されていることが多い．ドライブレ コーダやデジタルタコグラフでは，急加速・急減速は検出できるものの，このような潜在的な危険の検出 は困難であり，またドライバーからの報告もないため，運行管理者は潜在的に危険なヒヤリハットが実際 にどれくらいの頻度で発生しているのか把握することができず，ドライバーへの指導に反映させることも できない

(b) 客観的かつ総合的なドライバー評価の于段：ドライバーの評価を行う際に，評価を実施する運行管理者に よって評価の尺度がぶれてしまうと，ドライバーのモチベーション低下や運行管理者に対する不信を招く ため，人の主観によらない客観的な評価手段が望ましい. しかしながら，現状の運行管理システムでは， 速度超過や，急加速・急減速の頻度など速度面の評価は可能であるが，安全確認などそれ以外の項目につ いての評価軸が不足しており，運転技能に関する総合的な評価の際には，人の主観的な評価に頼らざるを 得ないことが多い.

(c) ドライバーの運転技能の直観的な把握 : 今回調査対象としたどの事業者においても，運行管理者は他業務 を兼務しており，ドライバー一人一人の毎日の運転に目を配る時間をもつことが困難である.もし，一人 一人のドライバーの運転技能を得点化できれば，毎日の得点の変化を見ることでドライバーの変調の兆し を一目で把握することができる．また，社内のドライバーの得点を比較することで，各ドライバーの運転 技能の弱い点を的確に把握でき，個別指導につなげることができるなど，運行管理において様々な用途が 期待できる.

(d) 添乗指導の頻度：今回調査対象としたどの事業者も，専任の指導員を設けておらすす，運行管理者，ある いは経験の長いドライバーが業務の合間に添乗指導を行っている．そのため，指導の効果が持続するのは 長くとも数か月であるにもかかわらず，ドライバーが添㭟指導を受ける頻度は一人あたり 1 年に 1 回程度 にとどまっている．もし運行管理者が添乗せずとも，ドライバーに対し指導を行える仕組みがあれば，ド ライバーの安全意識を高いレベルで保つことができるため，運行管理上，非常に有用である.

以上のヒアリング結果より，我々は，(1)潜在的な危険を検出可能な仩組み，(2)客観性を持った指標による評価 と得点化, (3)ドライバーの成績の一覧機能, (4)ドライバーに対する自動かつリアルタイムの安全アドバイス提供 機能，の4 点を運行管理者のニーズとして抽出した.

Table1 Profiles of transportation companies we interviewed

\begin{tabular}{|c|c|c|c|c|c|c|c|c|c|}
\hline & \multirow{2}{*}{$\begin{array}{l}\text { Business } \\
\text { type }\end{array}$} & \multirow[t]{2}{*}{ Drivers } & \multirow{2}{*}{$\begin{array}{l}\text { Safety } \\
\text { managers }\end{array}$} & \multirow[t]{2}{*}{ Cars } & \multicolumn{3}{|c|}{ Safety driving system } & \multicolumn{2}{|c|}{ Point rating system } \\
\hline & & & & & $\begin{array}{l}\text { Digital } \\
\text { tachograph }\end{array}$ & $\begin{array}{l}\text { Drive } \\
\text { recorder }\end{array}$ & Others & Individual & All \\
\hline $\mathrm{A}$ & Truck & 67 & 4 & 60 & $\triangle$ & $\times$ & $x$ & $x$ & $x$ \\
\hline $\mathrm{B}$ & Truck & 200 & 9 & 200 & 0 & $\triangle$ & 0 & 0 & $\mathrm{O}$ \\
\hline $\mathrm{C}$ & Truck & 27 & 3 & 31 & $\mathrm{O}$ & $x$ & $x$ & $\mathrm{O}$ & $\mathrm{O}$ \\
\hline $\mathrm{D}$ & Truck & 24 & 1 & 20 & $\triangle$ & $\bigcirc$ & $\times$ & $\mathrm{O}$ & $x$ \\
\hline $\mathrm{E}$ & Truck & 60 & 2 & 80 & $\mathrm{O}$ & $x$ & $x$ & 0 & $x$ \\
\hline $\mathrm{F}$ & Truck & 23 & 2 & 23 & 0 & $x$ & 0 & $\mathrm{O}$ & 0 \\
\hline $\mathrm{G}$ & Truck & 20 & 9 & 20 & $\times$ & 0 & $x$ & O & $x$ \\
\hline $\mathrm{H}$ & Truck & 15 & 2 & 15 & $\bigcirc$ & $x$ & $\bigcirc$ & 0 & $\mathrm{O}$ \\
\hline $\mathrm{I}$ & Bus & 8 & 4 & 8 & $x$ & $\times$ & $x$ & & \\
\hline $\mathbf{J}$ & Bus & 17 & 4 & 24 & 0 & $x$ & $x$ & 0 & $x$ \\
\hline
\end{tabular}

$\bigcirc \cdot$ All $\Delta \cdot \cdot$ Only as for some vehicles $\times \cdot \cdot$ Not used 


\section{3. 予防型運輸安全マネジメントシステムの提案と評価}

$3 \cdot 1$ 運転技能自動評価システム

我々は, これまで小型軽量の無線加速度/角速度センサを取り付けた帽子をかぶるだけで, 安全確認動作の生起 を，80\%以上の精度（アイマークレコーダ比）で検出できる技術を，自動車教習所指導員の安全運転知識の体系 化技術と組み合わせ，運転終了後のバッチ処理によってドライバーの技能を自動で評㑋・得点化するシステム Objet を開発してきた ${ }^{(3,4)}$. Objetでは，ドライバーの運転行動を小型のセンサで常時計測しているため，通常の 運転の範疇から外れた逸脱動作はもちろんのこと，予防安全の観点から見れば当然なされるべき動作が生起して いないこと（見通しの悪い交差点に安全確認もせずに進入するなどの潜在的な危険を含む）も検出・評価できる. Objetによる自動評価結果は，運転の良し悪しを判定する用途であれば $90 \%$ 以上の精度で指導員の意見と一致す る ${ }^{(3,4)}$. Objet を用いた職業ドライバ一向け安全運転講習は, これまでに 3,000 名以上のドライバーに対する安全 運転教育に活用された実績がある.

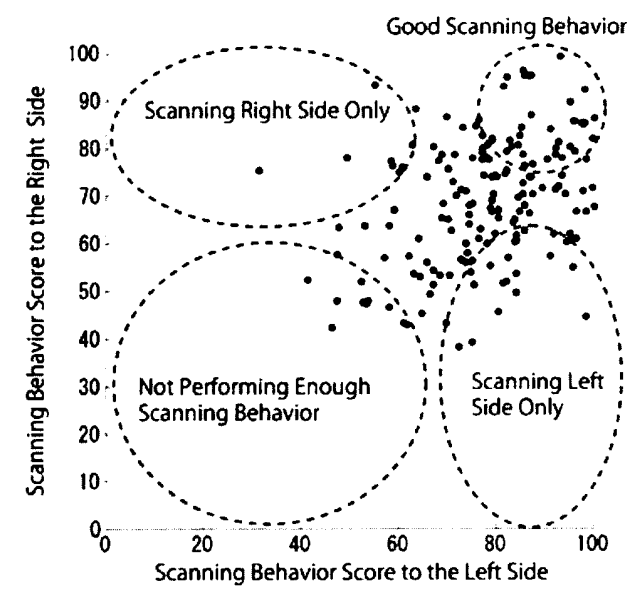

Fig.1 Drivers' skill Comparison System

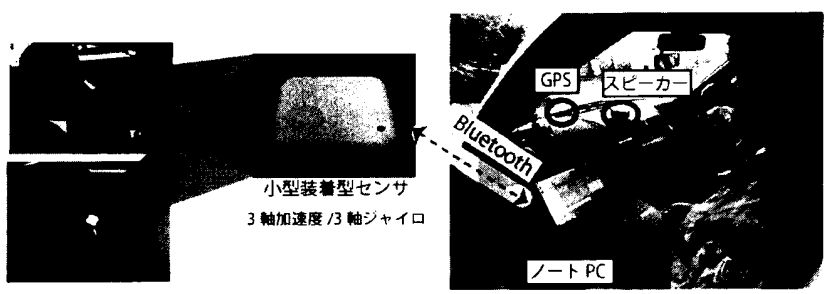

Fig.2 Real-time Safety Driving Advice System

\section{$3 \cdot 2$ 予防型運輸安全マネジメントシステム}

ここで, 2.2 節で抽出した運行管理者のニーズと, Objet 0 機能を比較する. Objet では, 運行管理者のニーズの うち，(1)潜在的な危険を検出可能な仕組みと(2)客観性を持った指標による評価と得点化，の機能はすでに実装し ている. 一方で, Objetはドライバー一人一人の評価結果を出すにとどまっており, (3)ドライバーの成績の一覧機 能は備えていない，また，Objet は運転終了後にバッチ処理によって評価を行うため，(4)ドライバーに対するリア ルタイムの安全アドバイス提供機能も備えていない，事後に評価を行う方式では，ドライバーが危険な運転をし たとしても，その場で改善を促す安全アドバイスを出すなど予防安全的なアプローチをとることができない.

そこで, 我々はObjet の機能を拡張し，ドライバーの成績を一覧表示する機能（図 1）および，ドライバーに 対してリアルタイムに安全アドバイスを提供する機能（図 2)，を実装し予防型運輸安全マネジメントシステムを 試作した。

$3 \cdot 3$ 試作システム評価

筆者らは，まず，リアルタイムの安全運転アドバイス提供の効果を調べるため, 自動車教習所指導員による安 全運転講習を実施した場合と, 指導員によらないリアルタイムの安全アドバイスを提供した場合とで, ドライバ 
一の運転行動の改善効果にどのような差が生じるのかを 20 名の被験者による実験で検証した ${ }^{(5)}$.その結果，リア ルタイムに安全アドバイスを提供することで, 従来の指導員による講習と同等の運転行動改善効果が得られるこ とを確認し，リアルタイムの安全アドバイス提供の有効性を確かめた ${ }^{(5)}$.

さらに, 我々は 2.2 節のヒアリング調查対象の事業者のうち 4 社, 運行管理者 5 名に対して, 試作した了防型運輸安 全マネジメントシステムの有用性に関するヒアリング調査を再度実施した. その結果, 「評価項目から各ドライバ 一の弱い点の把握がしやすい,「客観性を持った評価指標であるため,複数の運行管理者による評価であっても， その評価尺度が統一できる」，「運転技能を即座に評価でき,さらにその評価尺度が明確であるため, 提供された安 全アドバイスに対しドライバーも納得して，それを運転技能の向上に活かすことができる」「「添乗指導と同様の効果が 期待できる」など，好意的な評価を得た。

一方で，今回の試作システムに対する改善要望として，「カーブの曲がり方やブレーキを踏むタイミングなど車 をうまく操る技術に関する評価項目もほしい」，「急加速・急减速をしないなどエコ運転につながる評価項目がほ しい」などが寄せられた。

\section{4. 結語}

本稿では，ヒヤリハットが起きた後の “事後対策”ではなく，ヒヤリハットを未然に防ぐ“予防的な措置”を 目指した予防型運輸安全マネジメント支援システムの検討を行った. 我々は，まず運行管理者 16 名に対するヒア リング調查を実施し，(1)潜在的な危険を検出可能な仕組み，(2)客観性を持った指標による評価と得点化，(3)ドラ イバーの成績の一覧機能, (4)ドライバーに対する自動かつリアルタイムの安全アドバイス提供機能, の 4 点を二 ーズとして抽出した。このニーズをもとに，我々はこれまで開発してきた運転技能自動評価システム Objet 0 機 能を拡張した予防型運輸安全マネジメント支援システムを試作し，運行管理者から好意的な評価を得た。

我々は今年度後半, 運輸事業者と連携し, 試作システムを業務中に使用してもらう実証実験を実施する予 定である.この実証実験を通じて，現場のニーズを開発にフィードバックし，安全安心な交通社会の害現に 資するシステムの実現を目指していきたい.

\section{5. 謝辞}

本研究は, JST 研究成果最適展開支援プログラム「事故を未然に防止寸る予防型運輸安全マネジメント支援シ ステムの研究開発」として実施されたものである.

\section{文献}

(1)国土交通省，トラック，バス，タクシーの安全教育マニュアル， http://www.mlit.go.jp/jidosha/anzen/03safety/instruction.html（参照日 2012 年 7 月 8 日）

(2)国土交通省，運輸安全取組事例，http://www.mlit.go.jp/unyuanzen/List.html（参照日2012 年 7 月 8 日）

(3)多田昌裕，“装着型センサを用いた運転技能自動評価システムとその応用”，自動車技術，Vol.64，No.10， pp.66-71(2010)

(4)多田昌裕，“運転挙動データベースを用いた運転者の運転傾向の抽出”，日経エレクトロニクス， No.1083，5月 28 日号, pp.92-97(2012)

(5)多田昌裕, 野間春生，天野圭子，岡田昌也，蓮花一己，“運転技能自動評価技術に基ぶくリアルタイム安全運転ア ドバイス提供システムの提案”，映像情報メディア学会技術報告，Vol. 36，No.19，pp.5-9(2012) 